\title{
EXTREME MATERIAL POVERTY AS A NEGATIVE PREREQUISITE FOR THE TRANSFER OF AN APPLICANT FOR INTERNATIONAL PROTECTION TO THE COMPETENT MEMBER STATE AND FOR THE REJECTION OF AN APPLICATION FOR THE GRANT OF REFUGEE STATUS AS BEING INADMISSIBLE
}

\author{
Izabela Wróbel*
}

\author{
ABSTRACT
}

The essential measures for a common European asylum system adopted by EU institutions include Regulation (EU) No 604/2013 and Directive 2013/32/ $\mathrm{EU}$. These acts relate to the various stages of the functioning of the common European asylum system, however, there may be a risk of a violation of the fundamental rights of applicants as set out in the Charter of Fundamental Rights of the EU, including the prohibition on inhuman or degrading treatment (Article 4 of the Charter), at both stages. Such a risk may arise as a result of deficiencies in the asylum systems of the Member States. If these deficiencies are to fall within the scope of Article 4 of the Charter, they must attain a particularly high level of severity, which depends on all the circumstances of the case. An example of attaining this particularly high level of severity is the situation of extreme material poverty. As acts of the EU asylum law do not contain the terms "particularly high level of severity" and "extreme material poverty" and all the more they do not define them, guidelines on how to interpret and apply Article 4 of the Charter in the context of the common European asylum system should be sought in the case law of the Court of Justice of the EU. Therefore, the aim of the article is to explore and attempt to generalise and develop the basis and the criteria indicated

Associate Professor, Hab. in Law, PhD in Law, Head of the Research Centre for Legal and Economic Issues of Contemporary International Migration at the WSB University in Wrocław, Attorney-at-Law - Member of the Wrocław Bar Association of Attorneys-at-Law; izabela.wrobel@wsb.wroclaw.pl 
by the CJEU for assessing the actual nature of deficiencies in the asylum system of the Member State in question from the point of view of the prohibition laid down in Article 4 of the Charter, with particular emphasis on the criterion of a particularly high level of severity and the situation of extreme material poverty which meets this criterion.

Key words: EU asylum law, Regulation (EU) No 604/2013, Directive 2013/32/ EU, Charter of Fundamental Rights of the EU, extreme material poverty

\section{INTRODUCTION}

The essential measures for a common European asylum system adopted by the institutions of the European Union pursuant to Article 78(2) of the Treaty on the Functioning of the European Union ${ }^{1}$ include Regulation (EU) No 604/2013² (the Dublin III Regulation) and Directive 2013/32/EU ${ }^{3}$ (the Procedures Directive) ${ }^{4}$. These acts relate to the various stages of the functioning of the common European asylum system (the Dublin procedure precedes the actual procedure for granting international protection), however, there may be a risk of a violation of the fundamental rights of applicants as set out in the Charter of Fundamental Rights of the European Union (the Charter) ${ }^{5}$ at both stages. Such a risk may arise as a result of deficiencies in, or the collapse of,

1 Consolidated version of the Treaty on the Functioning of the European Union, 2016 OJ C 202/47.

2 Regulation (EU) No 604/2013 of the European Parliament and of the Council of 26 June 2013 establishing the criteria and mechanisms for determining the Member State responsible for examining an application for international protection lodged in one of the Member States by a third-country national or a stateless person, 2013 OJ L 180/31.

3 Directive 2013/32/EU of the European Parliament and of the Council of 26 June 2013 on common procedures for granting and withdrawing international protection, 2013 OJ L $180 / 60$.

4 See Kris Pollet, "A Common European Asylum System under Construction: Remaining Gaps, Challenges and Next Steps", In: Reforming the Common European Asylum System: The New European Refugee Law, ed. Vincent Chetail, Philippe De Bruycker, Francesco Maiani, Leiden and Boston: Brill Nijhoff, 2016, 74.

5 Consolidated version of the Charter of Fundamental Rights of the European Union, 2016 OJ C 202/389. 
asylum systems of the Member States. The aforementioned fundamental rights of applicants encompass the prohibition of inhuman or degrading treatment referred to in Article 4 of the Charter. The provision binding both stages in this respect is the second subparagraph of Article 3(2) of the Dublin III Regulation, according to which it is impossible to transfer an applicant to the Member State designated as responsible for examining an application for international protection, when there are substantial grounds for believing that there are systemic flaws in the asylum procedure and in the reception conditions for applicants in that Member State, resulting in a risk of inhuman or degrading treatment within the meaning of Article 4 of the Charter. Such systemic flaws may also appear at the next stage of the functioning of the common European asylum system, i.e. after granting international protection, within the scope of such protection. Their consequence will then be the inability to apply Article 33(2) (a) of the Procedures Directive authorising Member States to consider an application for international protection as inadmissible if another Member State has granted international protection.

As emphasised by the Court of Justice of the European Union (CJEU), having regard to the general and absolute nature of the prohibition laid down in Article 4 of the Charter, which is closely linked to respect for human dignity and which prohibits, without any possibility of derogation, inhuman or degrading treatment in whatever form, it is immaterial, for the purposes of the application of Article 4, that it is at the very moment of the transfer to the Member State that is responsible within the meaning of the Dublin III Regulation, in the course of the asylum procedure or on the conclusion of that procedure, that the person concerned would be exposed to a serious risk of suffering such treatment ${ }^{6}$. It should be added that, for the purposes of applying Article 4 of the Charter, not only systemic but also generalised deficiencies and deficiencies affecting certain groups of people require considera-

6 CJEU, Abubacarr Jawo v. Bundesrepublik Deutschland, Judgment, Case C-163/17, 19 March 2019, ECLI:EU:C:2019:218, para. 88; CJEU, Bashar Ibrahim and Others v. Bundesrepublik Deutschland and Bundesrepublik Deutschland v. Taus Magamadov, Judgement, Joined Cases C-297/17, C-318/17, C-319/17 and C-438/17, 19 March 2019, ECLI:EU:C:2019:219, para. 87. 
tion $^{7}$. However, if these above-mentioned deficiencies, whether systemic or generalised, or affecting certain groups of people, are to fall within the scope of Article 4 of the Charter, they must attain a particularly high level of severity, which depends on all the circumstances of the case. An example of attaining this particularly high level of severity is the situation of extreme material poverty, arising with no relation to the person's wishes and choices.

As acts of the EU asylum law do not contain the terms "particularly high level of severity" and "extreme material poverty" and all the more they do not define them, guidelines on how to interpret and apply Article 4 of the Charter in the context of the common European asylum system should be sought in the case law of the CJEU and the European Court of Human Rights (ECtHR). Therefore, the aim of the article is to explore and attempt to generalise and develop the basis and the criteria indicated by the CJEU for assessing the actual nature of deficiencies in the asylum system of the Member State in question from the point of view of the prohibition laid down in Article 4 of the Charter, with particular emphasis on the criterion of a particularly high level of severity and the situation of extreme material poverty which meets this criterion.

\section{TRANSFER OF AN APPLICANT FOR INTERNATIONAL PROTECTION UNDER THE DUBLIN SYSTEM, AND PROHIBITION OF INHUMAN OR DEGRADING TREATMENT}

It is settled case law of the CJEU that the provisions of the Dublin III Regulation must be interpreted and applied in a manner consistent with the fundamental rights guaranteed by the Charter, inter alia Article 4 thereof, which corresponds to Article 3 of the European Convention on Human Rights (ECHR). The meaning and scope of Article 4 of the

7 See CJEU, Abubacarr Jawo v. Bundesrepublik Deutschland, para. 90; CJEU, Bashar Ibrahim and Others v. Bundesrepublik Deutschland and Bundesrepublik Deutschland v. Taus Magamadov, para. 88. See also Sonia Morano-Foadi, "Solidarity and Responsibility: Advancing Humanitarian Responses to EU Migratory Pressures", European Journal of Migration and Law 19(2017): 236. 
Charter are, in accordance with Article 52(3) of the Charter, the same as those conferred on it by that convention. The prohibition of inhuman or degrading treatment or punishment, laid down in Article 4 of the Charter, is, in that regard, of fundamental importance, to the extent that it is absolute in that it is closely linked to respect for human dignity, which is the subject of Article 1 of the Charter ${ }^{8}$. Articles 1 and 4 of the Charter and Article 3 ECHR enshrine one of the fundamental values of the Union and its Member States. Therefore, the transfer of an asylum seeker to the Member State responsible within the framework of the Dublin III Regulation can take place only in conditions which preclude that transfer from resulting in a real risk of the person concerned suffering inhuman or degrading treatment, within the meaning of Article 4 of the Charter ${ }^{10}$. For example, a transfer might not be effected if, following the arrival of an unusually large number of third-country nationals seeking international protection, such a risk existed in the Member State responsible ${ }^{11}$.

The CJEU's case law shows that it follows from Article 3(2) of the Dublin III Regulation that the existence of systemic flaws in the asylum procedure and in the conditions for the reception of applicants for asylum in the Member State responsible, which provide substantial grounds for believing that the applicant for asylum would face a real risk of being subjected to inhuman or degrading treatment within the meaning of Article 4 of the Charter, is capable of affecting the obligation to transfer an asylum seeker to that Member State ${ }^{12}$. However, that provision cannot be

8 CJEU, C. K. and Others v. Republika Slovenija, Judgment, Case C-578/16 PPU, 16 February 2017, ECLI:EU:C:2017:127, para. 59; CJEU, Abubacarr Jawo v. Bundesrepublik Deutschland, paras. 67 and 78.

9 CJEU, PálAranyosi and Robert Căldăraruv. Generalstaatsanwaltschaft Bremen, Judgement, Joined Cases C-404/15 and C-659/15 PPU, 5 April 2016, ECLI:EU:C:2016:198, para. 87.

10 CJEU, C. K. and Others v. Republika Slovenija, para. 65.

11 CJEU, A.S. v. Republika Slovenija, Judgment, Case C-490/16, 26 July 2017, ECLI:EU:C:2017:585, para. 41; CJEU, Khadija Jafari, Zainab Jafari v. Bundesamt für Fremdenwesen und Asyl, Judgment, Case C-646/16, ECLI:EU:C:2017:586, para. 101.

12 See CJEU, Bundesrepublik Deutschland v. Kaveh Puid, Judgment, Case C-4/11, 14 November 2013, ECLI:EU:C:2013:740, paras. 30 and 36; CJEU, Shamso Abdullahi v. Bundesasylamt, Judgment, Case C-394/12, 10 December 2013, ECLI:EU:C:2013:813, paras. 60 and 62 . 
interpreted as excluding the possibility that considerations linked to real and proven risks of inhuman or degrading treatment, within the meaning of Article 4 of the Charter, might in exceptional situations have consequences for the transfer of a particular asylum seeker. Another reading of Article 3(2) of the Dublin III Regulation would be, first, irreconcilable with the general character of Article 4 of the Charter, which prohibits inhuman or degrading treatment in all its forms. Secondly, it would be manifestly incompatible with the absolute character of that prohibition if the Member States could disregard a real and proven risk of inhuman or degrading treatment affecting an asylum seeker under the pretext that it does not result from a systemic flaw in the Member State responsible. That interpretation fully respects the principle of mutual trust since, far from affecting the existence of a presumption that fundamental rights are respected in each Member State, it ensures that the exceptional situations are duly taken into account by the Member States. Moreover, if a Member State were to proceed with the transfer of an asylum seeker in such situations, the resulting inhuman and degrading treatment would not be attributable to the authorities of the Member State responsible, but to the first Member State alone ${ }^{13}$.

The jurisprudence of the CJEU reiterates that the principle of mutual trust between the Member States requires, particularly as regards the area of freedom, security and justice, of which the common European asylum system is a part, each of those States, save in exceptional circumstances, to consider all the other Member States to be complying with EU law and particularly with the fundamental rights recognised by EU law ${ }^{14}$. Accordingly, in the context of the common European asylum system, and in particular the Dublin III Regulation, which is based on the principle of

13 CJEU, Mehrdad Ghezelbash v. Staatssecretaris van Veiligheid en Justitie, Judgment, C-63/15, 7 June 2016, ECLI:EU:C:2016:409, para. 37; CJEU, George Karim v. Migrationsverket, Judgment, C-155/15, 7 June 2016, ECLI:EU:C:2016:410, para. 22; CJEU, C. K. and Others v. Republika Slovenija, paras. 91 to 93 and 95.

14 CJEU, Pál Aranyosi and Robert Căldăraru v. Generalstaatsanwaltschaft Bremen, para. 78; CJEU, LM, Judgment, Case C-216/18 PPU, 25 July 2018, ECLI:EU:C:2018:586, para. 36; CJEU, Abubacarr Jawo v. Bundesrepublik Deutschland, para. 81; CJEU, Bashar Ibrahim and Others v. Bundesrepublik Deutschland and Bundesrepublik Deutschland v. Taus Magamadov, para. 84. 
mutual trust, it must be presumed that the treatment of applicants for international protection in all Member States complies with the requirements of the Charter, the Convention relating to the Status of Refugees, signed in Geneva on 28 July 1951 (the Geneva Convention), and the ECHR. It is not however inconceivable that that system may, in practice, experience major operational problems in a given Member State, meaning that there is a substantial risk that applicants for international protection may, when transferred to that Member State, be treated in a manner incompatible with their fundamental rights including the prohibition of inhuman or degrading treatment or punishment. In those circumstances, the application of an irrebuttable presumption that the applicant for international protection would not be subjected to inhuman or degrading treatment in the Member State which, pursuant to the Dublin III Regulation, is designated as responsible for examining the application is incompatible with the duty to interpret and apply that regulation in a manner consistent with fundamental rights ${ }^{15}$.

To sum up, although the second subparagraph of Article 3(2) of the Dublin III Regulation envisages only the situation in which the real risk of inhuman or degrading treatment, within the meaning of Article 4 of the Charter, stems from systemic flaws in the asylum procedure and the reception conditions of applicants for international protection in the Member State which, pursuant to that regulation, is designated as responsible for examining the application, it is nevertheless apparent from the case law of the CJEU and from the general and absolute nature of the prohibition laid down in Article 4 of the Charter that the transfer of an applicant to that Member State is ruled out in any situation in which there are substantial grounds for believing that the applicant runs such a risk during his transfer or thereafter ${ }^{16}$. In that regard, where the court or tribunal hearing an action challenging a transfer decision has available to it evidence provided

15 CJEU, N. S. v. Secretary of State for the Home Department and M. E. and Others v. Refugee Applications Commissioner and Minister for Justice, Equality and Law Reform, Judgment, Joined Cases C-411/10 and C-493/10, 21 December 2011, ECLI:EU:C:2011:865, paras. 78 to 81 and 99, 100, 105; CJEU, Abubacarr Jawo v. Bundesrepublik Deutschland, paras. 82 to 84; CJEU, Bashar Ibrahim and Others v. Bundesrepublik Deutschland and Bundesrepublik Deutschland v. Taus Magamadov, paras. 85 and 86.

16 CJEU, Abubacarr Jawo v. Bundesrepublik Deutschland, para. 87. 
by the person concerned for the purposes of establishing the existence of such a risk, that court or tribunal is obliged to assess, on the basis of information that is objective, reliable, specific and properly updated and having regard to the standard of protection of fundamental rights guaranteed by EU law, whether there are deficiencies, which may be systemic or generalised, or which may affect certain groups of people ${ }^{17}$.

\section{POSSIBILITY OF REJECTING AN APPLICATION FOR THE GRANT OF REFUGEE STATUS AS BEING INADMISSIBLE, AND PROHIBITION OF INHUMAN OR DEGRADING TREATMENT}

In accordance with the view of the courts, the common European asylum system and the principle of mutual trust depend on the guarantee that the application of that system will not result, at any stage and in any form, in a serious risk of infringement of Article 4 of the Charter. It would, in that regard, be contradictory if the existence of such a risk at that stage of the asylum procedure were to prevent a transfer, while the same risk would be tolerated when that procedure has been completed with the recognition of international protection ${ }^{18}$. Accordingly, where a court or tribunal hearing an action brought against a decision rejecting a new application for international protection as being inadmissible has available to it evidence produced by the applicant in order to establish the existence of such a risk in the Member State that has previously granted subsidiary protection, that court or tribunal is obliged to assess, on the basis of information that is objective, reliable, specific and properly updated and having regard to the standard of protection of fundamental rights guaranteed by EU law, whether there are deficiencies, which may be systemic or generalised, or which may affect certain groups of people. The CJEU made clear that, having regard to the importance of the principle of mutual trust for the common European asylum system, infringements of the provisions of Chapter VII of the Directive 2011/95/

17 CJEU, Pál Aranyosi and Robert Căldăraru v. Generalstaatsanwaltschaft Bremen, para. 89; CJEU, Abubacarr Jawo v. Bundesrepublik Deutschland, para. 90.

${ }_{18}$ CJEU, Abubacarr Jawo v. Bundesrepublik Deutschland, para. 89. 
EU (the Qualification Directive) ${ }^{19}$ regarding the content of international protection which do not result in a breach of Article 4 of the Charter do not prevent the Member States from exercising the option granted by Article 33(2)(a) of the Procedures Directive ${ }^{20}$.

Both in relation to the Dublin procedure and in relation to the actual procedure for granting international protection, the CJEU used the expression "information that is objective, reliable, specific and properly updated". The case law of the CJEU, which mentions the obligation for a Member State to assess the existence of a real risk of inhuman or degrading treatment of individuals in another Member State, shows that information that is objective, reliable, specific and properly updated and that demonstrates that there are deficiencies, which may be systemic or generalised, or which may affect certain groups of people may be obtained from, inter alia, judgments of international courts, such as judgments of the ECtHR, judgments of courts of the Member State, and also decisions, reports and other documents produced by bodies of the Council of Europe or under the aegis of the United Nations ${ }^{21}$. The source of information that the Member State indicated as responsible by the criteria in the Dublin III Regulation is in breach of the rules of EU asylum law may be documents of the United Nations High Commissioner for Refugees (UNHCR). As pointed out by the CJEU, documents from the UNHCR are among the instruments likely to enable the Member States to assess the functioning of the asylum system in the Member State indicated as responsible by the Dublin criteria, and therefore to evaluate the risks to which the asylum seeker would actually be exposed were he to be transferred to that Member

19 Directive 2011/95/EU of the European Parliament and of the Council of 13 December 2011 on standards for the qualification of third-country nationals or stateless persons as beneficiaries of international protection, for a uniform status for refugees or for persons eligible for subsidiary protection, and for the content of the protection granted, 2011 OJ L 337/9.

20 CJEU, Bashar Ibrahim and Others v. Bundesrepublik Deutschland and Bundesrepublik Deutschland v. Taus Magamadov, para. 88 and 92.

21 CJEU, Pál Aranyosi, Robert Căldăraru, Judgment, Joined Cases C-404/15 and C-659/15 PPU, 5 April 2016, ECLI:EU:C:2016:198, para. 89; CJEU, Generalstaatsanwaltschaft (Conditions de détention en Hongrie), Judgment, Case C-220/18 PPU, 25 July 2018, ECLI:EU:C:2018:589, para. 60. 
State ${ }^{22}$. This can also apply to the Member State that has granted subsidiary protection and to the risks to which the beneficiary of subsidiary protection status would actually be exposed if he were to be stay in that Member State.

However, it seems that, as in the case of the execution of a European arrest warrant, a finding that there is a real risk of inhuman or degrading treatment in another Member State is not in itself sufficient. Whenever the existence of such a risk is identified, it is then necessary that the competent authority make a further assessment, specific and precise, of whether there are substantial grounds to believe that the individual concerned will be exposed to that risk because of his situation in another Member State. The mere existence of evidence that there are deficiencies, which may be systemic or generalised, or which may affect certain groups of people does not necessarily imply that, in a specific case, the individual concerned will be subject to inhuman or degrading treatment. Consequently, in order to ensure respect for Article 4 of the Charter in the individual circumstances of the asylum seeker or of the beneficiary of subsidiary protection status, the competent authority, when faced with evidence of the existence of such deficiencies that is objective, reliable, specific and properly updated, is bound to determine whether, in the particular circumstances of the case, there are substantial grounds to believe that the person will run a real risk of being subject in that Member State to inhuman or degrading treatment, within the meaning of Article 4 of the Charter ${ }^{23}$. It cannot be excluded that the assurance by another Member State that the person concerned will not be subjected to inhuman or degrading treatment within the meaning of Article 4 of the Charter can be taken into consideration. Such an assurance must be evaluated by carrying out an overall assessment of all the information available to the competent authority. In any event, giving such an assurance has been linked to the principle of sincere cooperation set out in the first subpara-

22 CJEU, Zuheyr Frayeh Halaf v. Darzhavna agentsia za bezhantsite pri Ministerskia savet, Judgment, Case C-528/11, 30 May 2013, ECLI:EU:C:2013:342, para. 44.

23 See CJEU, Pál Aranyosi, Robert Căldăraru, paras. 91 to 94; CJEU, Generalstaatsanwaltschaft (Conditions de détention en Hongrie), paras. 61 and 62. 
graph of Article 4(3) of the Treaty on the European Union ${ }^{24}$, which also applies under the common European asylum system. Anyway, the CJEU's general statement that, when implementing EU law, the Member States may, under EU law, be required to presume that fundamental rights have been observed by the other Member States, so that not only may they not demand a higher level of national protection of fundamental rights from another Member State than that provided by EU law, but also, save in exceptional cases, they may not check whether that other Member State has actually, in a specific case, observed the fundamental rights guaranteed by the European Union ${ }^{25}$ can be considered disputable as contrary to the absolute nature of the fundamental right guaranteed by Article 4 of the Charter.

\section{EXTREME MATERIAL POVERTY AS AN EXAMPLE OF A REAL RISK OF BEING SUBJECTED TO INHUMAN OR DEGRADING TREATMENT}

As regards the question of what criteria should guide the competent national authorities in carrying out the assessment, whether there are deficiencies in the asylum system of the Member State, it must be emphasised, according to the case law of the CJEU, that, in order to fall within the scope of Article 4 of the Charter, the deficiencies must attain a particularly high level of severity, which depends on all the circumstances of the case. That particularly high level of severity is attained where the indifference of the authorities of the Member State would result in a person wholly dependent on State support finding himself, irrespective of his wishes and personal choices, in a situation of extreme material poverty that does not allow him to meet his most basic needs, such as, inter alia, food, personal hygiene and a place to live, and that undermines his physical or mental health or puts him in a state of degradation incompatible with human dig-

24 See CJEU, Generalstaatsanwaltschaft (Conditions de détention en Hongrie), paras. 109,114 and 117.

25 Ibidem, para. 50; CJEU, Minister for Justice and Equality (Défaillances du système judiciaire), Judgment, Case C-216/18 PPU, 25 July 2018, ECLI:EU:C:2018:586, para. 37. 
nity ${ }^{26}$. Extreme material poverty puts a person in such a serious situation that it can be considered inhuman and degrading treatment ${ }^{27}$.

Interestingly, the ECtHR does not use the concept of "particularly high level of severity", but the term "minimum level of severity". The ECtHR has held on numerous occasions that to fall within the scope of Article 3 of the ECHR the ill-treatment must attain a minimum level of severity. The assessment of this minimum is relative - it depends on all the circumstances of the case, such as the duration of the treatment and its physical or mental effects and, in some instances, the sex, age and state of health ${ }^{28}$. In this way, a certain qualification is introduced in a norm formulated in absolute term ${ }^{29}$, although such a test to determine whether a particular form of ill-treatment violated Article 3 of the ECHR is based on the threshold, which is a difficult one to attain ${ }^{30}$. It should be added

26 CJEU, Abubacarr Jawo v. Bundesrepublik Deutschland, paras. 91 and 92; CJEU, Bashar Ibrahim and Others v. Bundesrepublik Deutschland and Bundesrepublik Deutschland v. Taus Magamadov, paras. 89 and 90; ECtHR, M.S.S. v. Belgium and Greece, Judgment, Appl. No. 30696/09, 21 January 2011, CE:ECHR:2011:0121JUD003069609, paras. 252 to 263. See also Andreas Pfersich, "Dublin-System, Überstellung des Asylbewerbers in den zuständigen Mitgliedstaat, Flucht, Verlängerung der Überstellungsfrist, ernsthaftes Risiko einer unmenschlichen oder erniedrigenden Behandlung nach Abschluss des Asylverfahrens, Lebensverhältnisse im Zielstaat EZAR NF 65 Nr. 71”, Zeitschrift für Ausländerrecht und Ausländerpolitik 5-6(2019): 198.

27 CJEU, Abubacarr Jawo v. Bundesrepublik Deutschland, para. 93; CJEU, Bashar Ibrahim and Others v. Bundesrepublik Deutschland and Bundesrepublik Deutschland v. Taus Magamadov, para. 91.

28 ECtHR, Kudta v. Poland, Judgment, Appl. No. 30210/96, 26 October 2000 , ECLI:CE:ECHR:2000:1026JUD003021096, para. 91; ECtHR, M.S.S. v. Belgium and Greece, para. 219; ECtHR, Tarakhel v. Switzerland, Judgment, Appl. No. 29217/12, 4 November 2014, ECLI:CE:ECHR:2014:1104JUD002921712, paras. 94 and 118; ECtHR, A.S. v. Switzerland, Judgment, Appl. No. 39350/13, 30 June 2015, ECLI:CE:ECHR:2015:0630JUD003935013, para. 26; ECtHR, V.M. and Others v. Belgium, Judgment, Appl. No. 60125/11, 7 July 2015, ECLI:CE:ECHR:2015:0707JUD006012511, para. 132. See also Nikolaos Sitaropoulos, "Migrant Ill-treatment in Greek Law Enforcement - Are the Strasbourg Court Judgments the Tip of the Iceberg?", European Journal of Migration and Law 19(2017): 141.

29 Pieter van Dijk, Godefridus J. H. van Hoof, Theory and Practice of the European Convention on Human Rights, The Hague, London and Boston: Kluwer Law International, 1998, 312 .

30 Uğur Erdal, Hasan Bakirci, Article 3 of the European Convention on Human Rights: A Practitioner's Handbook, Geneva: World Organisation Against Torture, 2006, 123 and 124. 
that the interpretation of the ECHR is a living instrument and conduct which previously had not attained the threshold for categorization as inhuman or degrading treatment might be so categorised in the future ${ }^{31}$.

In the case of M.S.S. v. Belgium and Greece, which concerned an Afghan asylum-seeker who had been sent back to Greece by the Belgian authorities in accordance with the Dublin II Regulation ${ }^{32}$, the ECtHR considered that the Greek authorities have not had due regard to the applicant's vulnerability as an asylum-seeker and must be held responsible, because of their inaction, for the situation in which he has found himself for several months, living on the street, with no resources or access to sanitary facilities, and without any means of providing for his essential needs. The ECtHR also took into account that the applicant has been the victim of humiliating treatment showing a lack of respect for his dignity and that this situation has, without doubt, aroused in him feelings of fear, anguish or inferiority capable of inducing desperation. It considered that such living conditions, combined with the prolonged uncertainty in which he has remained and the total lack of any prospects of his situation improving, have attained the level of severity required to fall within the scope of Article 3 of the ECHR ${ }^{33}$. At other times the ECtHR talked about the "obligation not to expose the applicants to conditions of extreme poverty for four weeks" 34 . So it doesn't have to be months. In fact, both Courts the ECtHR and the CJEU - speak of the same level of severity and EU law is without influence on the case law of the ECtHR.

With the case of M.S.S. v. Belgium and Greece the ECtHR initiated a change in its case law. After noting that the obligation to provide accommodation and decent material conditions to impoverished asylum seekers had entered into positive law and the Member States' authorities were bound to comply with their own legislation transposing EU law, namely

31 Bernadette Rainey, Elizabeth Wicks, Clare Ovey, Jacobs, White and Ovey: The European Convention on Human Rights, Oxford: Oxford University Press, 2014, 171.

32 Council Regulation (EC) No 343/2003 of 18 February 2003 establishing the criteria and mechanisms for determining the Member State responsible for examining an asylum application lodged in one of the Member States by a third-country national, 2003 OJ L 50/1.

33 ECtHR, M.S.S. v. Belgium and Greece, para. 263.

34 ECtHR, V.M. and Others v. Belgium, para. 162. 
the Directive 2003/9/EC (the Reception Directive) ${ }^{35}$, the ECtHR held that, in determining whether the threshold of severity required by Article 3 of the ECHR had been attained, particular importance had to be attached to the applicant's status as an asylum-seeker. Accordingly, he belonged to a particularly underprivileged and vulnerable population group in need of special protection. The ECtHR noted the existence of a broad consensus at the international and European level concerning this need for special protection, as evidenced by the Geneva Convention, the remit and the activities of the UNHCR, and the standards set out in the Reception Directive ${ }^{36}$.

In the ECtHR's assessment the requirement of "special protection" of asylum seekers is particularly important when the persons concerned are children, in view of their specific needs and their extreme vulnerability. This applies even when the children seeking asylum are accompanied by their parents. Children have specific needs that are related in particular to their age and lack of independence, but also to their asylum seeker status. The ECtHR has also observed that the Convention on the Rights of the Child encourages States to take the appropriate measures to ensure that a child who is seeking to obtain refugee status enjoys protection and humanitarian assistance, whether the child is alone or accompanied by his or her parents. Accordingly, the reception conditions for children seeking asylum must be adapted to their age, to ensure that those conditions do not create for them a situation of stress and anxiety, with particularly traumatic consequences. Otherwise, the conditions in question would attain the threshold of severity required to come within the scope of the prohibition under Article 3 of the ECHR ${ }^{37}$.

35 Council Directive 2003/9/EC of 27 January 2003 laying down minimum standards for the reception of asylum seekers, 2003 OJ L 31/18, repealed by Directive 2013/33/ EU of the European Parliament and of the Council of 26 June 2013 laying down standards for the reception of applicants for international protection. 2013 OJ L 180/96.

36 ECtHR, M.S.S. v. Belgium and Greece, para. 251; ECtHR, Tarakhel v. Switzerland, paras. 96, 97 and 118; ECtHR, A.S. v. Switzerland, paras. 28 and 29. ECtHR, V.M. and Others v. Belgium, para. 136.

37 ECtHR, Popov v. France, Judgment, Appls. Nos. 39472/07 and 39474/07, 19 January 2012, ECLI:CE:ECHR:2012:0119JUD003947207, paras. 91 and 102; ECtHR, Tarakhel v. Switzerland, paras. 99 and 119. 
It is true that in its case law the ECtHR has had regard to the vulnerability of the applicants both in assessing whether the threshold of severity justifying the application of Article 3 of the ECHR had been attained (a greater degree of vulnerability justifying a lower threshold of tolerance) and in determining the scope of the positive obligations on the State (extreme vulnerability requiring a greater duty of protection) $)^{38}$. However, as Lieneke Slingenberg rightly pointed out, apart from referring to the broad consensus at the international and European level, the ECtHR does not provide any arguments as to why asylum seekers should be considered to be particularly underprivileged and vulnerable ${ }^{39}$. In the case of M.S.S. v. Belgium and Greece, the ECtHR accepted that the applicant, who was an adult asylum seeker, was a vulnerable person because of his past traumatic experiences but it also more generally indicated that vulnerability is an inherent characteristic of asylum seekers. Thus, the ECtHR interprets vulnerability as a label that is tagged on and inherent to the situation of asylum seekers, but it is impossible to deny that not all persons belonging to a vulnerable group, even children, have the same vulnerabilities, experiences or needs ${ }^{40}$. The CJEU does not seem to share the ECtHR's view about the group vulnerability when it speaks of the applicant's particular vulnerability.

It is important to note that the Reception Directive introduces far-reaching clarity in this respect - in Article 21 it defines a vulnerable person by way of exemplary but detailed enumeration. This provision states that,

"Member States shall take into account the specific situation of vulnerable persons such as minors, unaccompanied minors, disabled people, elderly people, pregnant women, single parents with minor children, victims of human trafficking, persons with serious illnesses, persons with mental

38 ECtHR, V.M. and Others v. Belgium, Dissenting opinion of judge Ranzoni, joined by judges López Guerra, Sicilianos and Lemmens, para. 5.

39 Lieneke Slingenberg, The Reception of Asylum Seekers under International Law: Between Sovereignty and Equality, Oxford and Portland, Oregon: Hart Publishing, 2014, 297.

40 Julie Ryngaert, Wouter Vandenhole, "Undocumented migration: integrating the children's rights concept of nuanced vulnerability in human rights law”, In: Children's Rights Law in the Global Human Rights Landscape. Isolation, Inspiration, Integration?, ed. Eva Brems, Ellen Desmet, Wouter Vandenhole, London and New York: Routledge, 2017, 217 and 218. 
disorders and persons who have been subjected to torture, rape or other serious forms of psychological, physical or sexual violence, such as victims of female genital mutilation, in the national law implementing this Directive".

What is more, as stipulated in article 22(3) of the Reception Directive, only vulnerable persons in accordance with Article 21 of this Directive may be considered to have special reception needs and thus benefit from the specific support provided in accordance with this Directive. A similar, though not identical, definition of a vulnerable person is included in Article 20(3) of the Qualification Directive. This second definition was formulated for the purpose of chapter VII of the Qualification Directive ("Content of international protection"). In this regard, the EU approach to asylum seekers and, even more so, beneficiaries of international protection are not consistent with the case law of the ECtHR. However, the ECtHR's view deserves criticism and sooner or later, as unclear or incomplete (one can probably speak about the gradeability of vulnerability), it will have to be adapted under the influence of EU standards as correct, and therefore only appropriate from the point of view of life experience and scientific achievements.

As the ECtHR pointed out, the assessment of the existence of a real risk of being subjected to treatment contrary to Article 3 of the ECHR must necessarily be a rigorous one, in view of the absolute character of Article 3 of the ECHR and the fact that it enshrines one of the fundamental values of the democratic societies making up the Council of Europe. The competent authority should take as its basis all the material placed before it or, if necessary, material obtained proprio motu ${ }^{41}$. As is clear from the case law of the CJEU, the existence of shortcomings in the implementation, by the Member State normally responsible for examining the application for international protection, of programmes to integrate the beneficiaries of that protection cannot constitute a substantial ground for believing that

${ }^{41}$ ECtHR, Chahal v. the United Kingdom, Judgment, Appl. No. 22414/93, 15 November 1996, ECLI:CE:ECHR:1996:1115JUD002241493, para. 96; ECtHR, Saadi v. Italy, Judgment, Appl. No. 37201/06, 28 February 2008, ECLI:CE:ECHR:2008:0228JUD003720106, para. 128; ECtHR, S.H.H. v. the United Kingdom, Judgment, Appl. No. 60367/10, 29 January 2013, ECLI:CE:ECHR:2013:0129JUD006036710, para. 71. 
the person concerned would be exposed, in the event of transfer to that Member State, to a real risk of being subjected to inhuman or degrading treatment, within the meaning of Article 4 of the Charter. Nevertheless, it cannot be ruled out that an applicant for international protection may be able to demonstrate the existence of exceptional circumstances that are unique to him and mean that, in the event of transfer to the Member State normally responsible for processing his application for international protection, he would find himself, because of his particular vulnerability, irrespective of his wishes and personal choices, in a situation of extreme material poverty meeting the criteria set out by the CJEU after having been granted international protection ${ }^{42}$. Also, the fact that those granted subsidiary protection do not receive, in the Member State which granted such protection to the applicant, any subsistence allowance, or that such allowance they receive is markedly inferior to that in other Member States, though they are not treated differently from nationals of that Member State, that can lead to the finding that that applicant is exposed in that Member State to a real risk of suffering treatment that is in breach of Article 4 of the Charter only if the consequence is that the applicant is, because of his particular vulnerability, irrespective of his wishes and personal choices, in a situation of extreme material poverty that meets the criteria that recognises the existence of such a situation ${ }^{43}$, i.e. a particularly high level of severity, manifested in the inability to meet most basic needs to the detriment of physical or mental health or in the state of degradation which violates human dignity, or in the position which is so serious that it deserves to be called inhuman or degrading treatment. Furthermore, the mere fact that social protection or living conditions are more favourable in the requesting Member State than the Member State normally responsible for examining the application for international protection is not capable of supporting the conclusion that the person concerned would be exposed, in the event of transfer to the latter Member State, to a real risk of suffering treatment contrary to Article 4 of the Charter ${ }^{44}$. Similarly,

${ }_{42}$ CJEU, Abubacarr Jawo v. Bundesrepublik Deutschland, paras. 95 and 96.

43 CJEU, Bashar Ibrahim and Others v. Bundesrepublik Deutschland and Bundesrepublik Deutschland v. Taus Magamadov, para. 93.

${ }_{44}$ CJEU, Abubacarr Jawo v. Bundesrepublik Deutschland, para. 97. 
the mere fact that social protection or living conditions are more favourable in the Member State to which the new application for international protection has been made than in the Member State that has previously granted subsidiary protection cannot support the conclusion that the person concerned would be exposed, in the event of a transfer to the latter Member State, to a real risk of suffering treatment in breach of Article 4 of the Charter ${ }^{45}$.

In this context it should be recalled that the EU legislature did not confine itself, in Regulation (EU) No 604/2013, to introducing organisational rules simply governing relations between Member States for the purpose of determining the Member State responsible, but decided to involve asylum seekers in that process by obliging Member States to inform them of the criteria for determining responsibility and to provide them with an opportunity to submit information relevant to the correct interpretation of those criteria, and by conferring on asylum seekers the right to an effective remedy in respect of any transfer decision that may be taken at the conclusion of that process ${ }^{46}$. According to the case law of the ECtHR, it is in principle for the applicant to adduce evidence capable of proving that there are substantial grounds for believing that, if the measure complained of were to be implemented, he would be exposed to a real risk of being subjected to treatment contrary to Article 3 of the ECHR. The ECtHR acknowledged that, owing to the special situation in which asylum seekers often find themselves, it is frequently necessary to give them the benefit of the doubt when it comes to assessing the credibility of their statements and the documents submitted in support thereof. However, when information is presented which gives strong reasons to question the veracity of an asylum seeker's submissions, the individual must provide a satisfactory

45 CJEU, Bashar Ibrahim and Others v. Bundesrepublik Deutschland and Bundesrepublik Deutschland v. Taus Magamadov, para. 94.

46 CJEU, Mehrdad Ghezelbash v. Staatssecretaris van Veiligheid en Justitie, para. 37. See Silvia Morgades-Gil, "The Right to Benefit from an Effective Remedy against Decisions Implying the Return of Asylum-seekers to European Safe Countries: Changes in the Right to Appeal in the Context of the European Union's Dublin System vis-à-vis International and European Standards of Human Rights", European Journal of Migration and Law 19(2017): 278 and 279. 
explanation for the alleged discrepancies ${ }^{47}$. Therefore, the applicant can and should be active in the Dublin or asylum procedure or in the proceedings before the court and the competent authority should always take into account the applicant's/complainant's particular situation ${ }^{48}$.

\section{CONCLUSIONS}

The Dublin III Regulation and the Procedures Directive, which form an integral part of the common European asylum system ${ }^{49}$, respect the fundamental rights and observe the principles which are acknowledged in the Charter. In particular, these acts seek to ensure full observance of, inter alia, the right recognised under Article 4 of the Charter ${ }^{50}$. The principle of mutual trust between the Member States and the presumption of respect, by the Member States, for fundamental rights are the foundation of the common European asylum System. Every asylum seeker and beneficiary of international protection has the right not to be subjected to inhuman and degrading treatment in the Member States. However, practice in the Member States may not be free of the risk of violating the prohibition of inhuman or degrading treatment. Such a risk may arise as a result of deficiencies (of different nature or scale) in the asylum systems of the Member States. In accordance with the well-established case law of the ECtHR, if the deficiencies are to fall within the scope of the prohibition of inhuman or degrading treatment, they must attain a certain level of severity, which depends on all the circumstances of the case. The test created by the ECtHR sets the bar very high. This test meets, inter alia, the situation of extreme material poverty.

47 ECtHR, S.H.H. v. The United Kingdom, para. 71.

48 See Fanny De Weck, Non-refoulement under the European Convention on Human Rights and the UN Convention against Torture: The Assessment of Individual Complaints by the European Court of Human Rights under Article 3 ECHR and the United Nations Committee against Torture under Article 3 CAT, Leiden and Boston: Brill Nijhoff, 2017, 351.

49 CJEU, Shiraz Baig Mirza v. Bevándorlási és Allampolgársági Hivatal, Judgment, Case C-695/15 PPU, 17 March 2016, ECLI:EU:C:2016:188, para. 42.

50 See recital 39 of the Dublin III Regulation and recital 60 of the Procedures Directive. 
The CJEU has not dealt with extreme material poverty as a negative prerequisite for the transfer of an applicant for international protection to the competent Member State under the Dublin III Regulation and for the rejection of an application for the grant of refugee status as being inadmissible on the basis of the Procedures Directive for a very long time. It did this for the first time in 2019 in cases of Abubacarr Jawo $v$. Bundesrepublik Deutschland and Bashar Ibrahim and Others v. Bundesrepublik Deutschland and Bundesrepublik Deutschland v. Taus Magamadov, referring to the ECtHR's case law. Regarding the prerequisite of extreme material poverty, the CJEU was very frugal in words. It did not complete the test created by the ECtHR and provided only examples of situations that do not meet the criteria of extreme material poverty. The CJEU did not refer to differences in approach to the issue (degree) of vulnerability in the entire group of asylum seekers and beneficiaries of international protection and its subgroups. However, it proposed a more accurate term than that used by the ECtHR - "particularly high level of severity" instead of "minimum level of severity". It also placed emphasis on traits and experiences (in other words individual particular vulnerability) of the applicant and - as a consequence - on an assessment of meeting the criteria of extreme material poverty on a case-by-case basis. Thereby, the vulnerability of the person concerned (individual, not group vulnerability) is a relevant factor for establishing whether the extreme material poverty has been achieved.

It is worth paying attention to some inconsistency of the CJEU. In its opinion, deficiencies in the asylum systems may be systemic or generalised, or may affect certain groups of people. But they can also have a one-time nature and affect only one person. On the other hand, if something affects the whole group, based on the criterion of belonging to this group, then it also affects its individual members and using such a presumption is justified. The position of the individual is unfortunately still not fully clear in the context of presumption that fundamental rights are respected in each Member State ${ }^{51}$. As usual, the main burden of assessing all the cir-

51 See Céline Bauloz, Meltem Ineli-Ciger, Sarah Singer, Vladislava Stoyanowa, ”Introducing the Second Phase of the Common European Asylum System", In: Seeking Asylum in the European Union: Selected Protection Issues Raised by the Second Phase of the 
cumstances of the case rests on the national authorities. In this respect, the interpretative guidelines contained in the judgments regarding extreme material poverty do not seem sufficient for law enforcement authorities in the Member States. It is necessary to refer to the previous case law of the CJEU itself and the EctHR, in particular with regard to the basis and method of assessment.

More generally, there is consensus in the comments that the Jawo and Ibrahim judgments of the CJEU are of great importance. Anthea Galea indicated that for the first time the CJEU provided the criteria that must guide the assessment carried out by the national authorities in determining whether there are deficiencies of a particularly high level of severity leading to a real risk of inhuman or degrading treatment. In contrast to previous rulings, the CJEU considered whether there can be a breach of Article 4 of the Charter by analysing the circumstances after the person is transferred to the requested Member State and granted international protection. This is the first time that the CJEU has taken into account the expected living conditions of the beneficiary of international protection in another Member State ${ }^{52}$. As noted by Marcel Keienborg, German administrative courts are increasingly dealing with cases in which persons seeking international protection claim that they have lost the support in another Member State after receiving international protection. They have to leave the shelters for those seeking protection, but in fact they have no access to the housing market in the host Member State. Homelessness and impoverishment are the result. In the jurisprudence of administrative courts in Germany, the view has so far dominated that such considerations are irrelevant in the Dublin procedure. The CJEU gave a clear rejection of this view. Also in cases of secondary migration (migration of beneficiaries of international protection) the German authorities must change the way these cases are handled ${ }^{53}$. Therefore, from the point of

Common European Asylum System, ed. Céline Bauloz, Meltem Ineli-Ciger, Sarah Singer, Vladislava Stoyanowa, Leiden and Boston: Brill Nijhoff, 2015, 11.

52 Anthea Galea, "The Jawo Case: The limits of the principle of mutual trust", European Law Blog, May 13, 2019, http://europeanlawblog.eu/2019/05/13/the-jawo-case-thelimits-of-the-principle-of-mutual-trust/.

53 Marcel Keienborg, "Auch bei Abschiebungen bleibt die Menschenwürde unantastbar", The Legal Tribune Online, March 20, 2019, https://www.lto.de/recht/hintergruende/h/eugh 
view of dogmatics of EU law and of practice within the common European asylum system, the Jawo and Ibrahim judgments should be included among the most important in recent years.

\section{REFERENCES}

Bauloz, Céline, Meltem Ineli-Ciger, Sarah Singer, Vladislava Stoyanowa. 2015. "Introducing the Second Phase of the Common European Asylum System". In: Seeking Asylum in the European Union: Selected Protection Issues Raised by the Second Phase of the Common European Asylum System, ed. Céline Bauloz, Meltem Ineli-Ciger, Sarah Singer, Vladislava Stoyanowa, 1-22. Leiden and Boston: Brill Nijhoff.

De Weck, Fanny. 2017. Non-refoulement under the European Convention on Human Rights and the UN Convention against Torture: The Assessment of Individual Complaints by the European Court of Human Rights under Article 3 ECHR and the United Nations Committee against Torture under Article 3 CAT. Leiden and Boston: Brill Nijhoff.

Dijk, Pieter van, Godefridus J. H. van Hoof. 1998. Theory and Practice of the European Convention on Human Rights. The Hague, London and Boston: Kluwer Law International.

Dörig, Harald. 2019. "Höchstrichterliche Rechtsprechung zum Asylrecht im Jahr 2018”. Zeitschrift für Ausländerrecht und Ausländerpolitik 3: 99-111.

Erdal, Uğur, Hasan Bakirci. 2006. Article 3 of the European Convention on Human Rights: A Practitioner's Handbook. Geneva: World Organisation Against Torture.

Galea, Anthea. 2019. "The Jawo Case: The limits of the principle of mutual trust". European Law Blog, May 13. [last access: 18.08.2019], http://europeanlawblog. eu/2019/05/13/the-jawo-case-the-limits-of-the-principle-of-mutual-trust/.

Keienborg, Marcel. 2019. "Auch bei Abschiebungen bleibt die Menschenwürde unantastbar". The Legal Tribune Online, March 20. [last access: 18.08.2019, https://www.lto.de/recht/hintergruende/h/eugh-c163-17-c297-17-c318-17c43817-asylantrag-entwuerdigende-behandlung-nach-anerkennung-sekundaermigration/.

-c163-17-c297-17-c318-17-c43817-asylantrag-entwuerdigende-behandlung-nach-anerkennung-sekundaermigration/; Harald Dörig, "Höchstrichterliche Rechtsprechung zum Asylrecht im Jahr 2018”, Zeitschrift für Ausländerrecht und Ausländerpolitik 3(2019): 110. 
Morano-Foadi, Sonia. 2017. "Solidarity and Responsibility: Advancing Humanitarian Responses to EU Migratory Pressures". European Journal of Migration and Law 19: 223-254.

Morgades-Gil, Silvia. 2017. "The Right to Benefit from an Effective Remedy against Decisions Implying the Return of Asylum-seekers to European Safe Countries: Changes in the Right to Appeal in the Context of the European Union's Dublin System vis-à-vis International and European Standards of Human Rights". European Journal of Migration and Law 19: 255-280.

Pfersich, Andreas. 2019. ”Dublin-System, Überstellung des Asylbewerbers in den zuständigen Mitgliedstaat, Flucht, Verlängerung der Überstellungsfrist, ernsthaftes Risiko einer unmenschlichen oder erniedrigenden Behandlung nach Abschluss des Asylverfahrens, Lebensverhältnisse im Zielstaat EZAR NF 65 Nr. 71". Zeitschrift für Ausländerrecht und Ausländerpolitik 5-6: 192-198

Pollet, Kris. 2016. "A Common European Asylum System under Construction: Remaining Gaps, Challenges and Next Steps". In: Reforming the Common European Asylum System: The New European Refugee Law, ed. Vincent Chetail, Philippe De Bruycker, Francesco Maiani, 74-100. Leiden and Boston: Brill Nijhoff.

Rainey, Bernadette, Elizabeth Wicks. 2014. Clare Ovey, Jacobs, White and Ovey: The European Convention on Human Rights. Oxford: Oxford University Press. Ryngaert, Julie, Wouter Vandenhole. 2017. ”Undocumented migration: integrating the children's rights concept of nuanced vulnerability in human rights law". In: Children's Rights Law in the Global Human Rights Landscape. Isolation, Inspiration, Integration?, ed. Eva Brems, Ellen Desmet, Wouter Vandenhole, 210-230. London and New York: Routledge.

Sitaropoulos, Nikolaos. 2017. "Migrant Ill-treatment in Greek Law Enforcement - Are the Strasbourg Court Judgments the Tip of the Iceberg?". European Journal of Migration and Law 19: 136-164.

Slingenberg, Lieneke. 2014. The Reception of Asylum Seekers under International Law: Between Sovereignty and Equality. Oxford and Portland, Oregon: Hart Publishing. 
